\title{
A POSSIBLE FUNCTION IN CELL-SUBSTRATE ADHESION OF A METABOLIC PRODUCT OF L-M CELLS ${ }^{1}$
}

\author{
MARY R. DANIEL ${ }^{2}$ \\ Department of Microbiology, University of Michigan, Ann Arbor, Mich., U.S.A. \\ Received September 5, 1966
}

Tirs work developed from an observation made during experiments designed to compare the metabolism of cells in suspension and in monolayer culture respectively. Cells from a suspension culture were spun down and resuspended in fresh medium; they were then distributed as suspension cultures, and as monolayer cultures on plastic, for comparison of glucose utilization and lactate and pyruvate production, per $10^{6}$ cells, after different periods of incubation. This comparison necessitated the harvesting of the cells from sample monolayers, after 24,48 and $72 \mathrm{hr}$ incubation, by scraping from the plastic. Routine checks of viability on the resulting suspensions indicated that, by comparison with cells grown in suspension for a comparable period, the $24 \mathrm{hr}$ monolayer, after being scraped from the plastic, had a low viability. On succeeding days, the viability of the cells obtained from the monolayers increased.

These findings suggested that some substance, produced by the cells during prolonged growth in monolayer culture, protected them from trauma on removal by scraping; and that this substance was either not produced by cells grown in suspension, or, if produced, was not attached to the surfaces of the cells and so did not protect them.

Further experiments were made to test this hypothesis, and to see if similar findings were obtained for cells grown for short periods on glass.

\section{MATERIALS AND METHODS}

For most of the experiments, the L-M cell line was used. This is a subline of Earle's "L" strain of mouse fibroblasts, adapted by Merchant [4], to grow in a protein-free medium consisting of a modified "199" (Eidam and Merchant, 1965) supplemented with 0.5 per cent "Difco" Bactopeptone. The L-M $2 \times \mathrm{E}$ cell line, which Merchant

\footnotetext{
1 This work was supported in part by grant no. CA-03720-09 from the National Cancer Institute, Bethesda, Md., U.S.A.

${ }^{2}$ Permanent address: Strangeways Research Laboratory, Cambridge, England.
} 
derived from the L-M line by growth in a chemically defined medium, was used for one experiment. This cell line is routinely grown in monolayer cultures in Eagle's medium containing twice the usual concentrations of amino acids and vitamins $(2 \times \mathrm{E})$.

Stock cultures of both lines were grown as monolayers on glass, and subcultured at weekly intervals. For subculture, the medium was replaced with fresh, and the cells were scraped from the surface of the bottle with a rubber policeman. The resulting suspension was pipetted several times to break up any cell clumps, and distributed among fresh culture bottles to which the required amount of medium had been added. To reduce injury to the more fragile L-M $2 \times \mathrm{E}$ cells during subculture, 0.12 per cent methyl cellulose (Dow "Methocel", $15 \mathrm{cps}$ ) was incorporated in the medium in which the cells were scraped from the glass.

Suspension cultures were grown in $250 \mathrm{mI}$ screw-capped Erlenmeyer flaks, agitated on a rotary shaker with a 1" radial stroke, at a speed of $110 \mathrm{rpm}$. Methocel was used at a concentration of 0.12 per cent in the medium for cells suspended in $199 /$ Peptone, and of 0.24 per cent for cells in $2 \times \mathbf{E}$.

The plastic culture vessels used in most of the experiments were "Falcon" tissue culture flasks, capacity $30 \mathrm{ml}$ (Falcon plastics); in one experiment, tissue culture dishes $(15 \times 60 \mathrm{~mm})$ manufactured by the same firm were used. These culture vessels are described by the makers as being made of "a pure polystyrene containing small amounts of organic lubricants" [3]. Except in one experiment, the glass bottles were new small French square bottles, made of soft glass, of which the surface area of a side was approximately equal to that of a plastic flask. Unless otherwise indicated, the glass bottles were washed only with tap and distilled water before being sterilized in the autoclave.

For most experiments, the cells were obtained from suspension cultures; these were prepared, two days before use, from cell suspensions made from freshly harvested monolayers and diluted to contain approximately $2.5 \times 10^{5} \mathrm{cells} / \mathrm{ml}$. When experimental monolayer cultures were to be initiated, total and viable cell counts of a 2 -day suspension culture were made; only cultures with a viability of over 90 per cent were used. For experiments in which cells suspended in the same medium were to be seeded onto different surfaces, the required volume of suspension was centrifuged, and the cells were resuspended in fresh medium at a concentration of approximately $2.5 \times 10^{5} / \mathrm{ml}$. If different media were to be used, aliquots of the suspension culture were centrifuged, and the cells from these were suspended in the appropriate media to give a cell density in each of approximately $2.5 \times 10^{5} / \mathrm{ml}$. The $\mathrm{pH}$ of each suspension was adjusted to an initial value of approximately 7.6. Methocel was incorporated in the media for these monolayer cultures at the same concentrations as for suspension cultures in the same media.

Except in experiments 1, 3 and 9, four bottles were used for each culture condition examined in an experiment. Five $\mathrm{ml}$ of suspension were pipetted into each flask, and the cultures were incubated at $37^{\circ} \mathrm{C}$ for the periods indicated under "Experiments and Results". The medium was then poured off and replaced with fresh 199 containing peptone and methocel $(199 \mathrm{P} \mathrm{mc})$; the cells were scraped from the surface of each flask with a rubber policeman and, after the suspension had been pipetted ten times to break up any cell clumps, samples were taken for total and viable cell counts.

Total cell counts were made with an electronic cell counter (Coulter Electronics, Model B), and the viability of each suspension was estimated by the erythrosin B dye 
exclusion test of Phillips and Terryberry [8], as described by Eidam and Merchant [2].

In experiments in which flask surfaces were treated with buffered solutions, the $\mathrm{pH}$ of these was adjusted to approximately 7.6 .

\section{EXPERIMENTS AND RESULTS}

Comparison of the viability of cells scraped from plastic, after varying periods of cultivation, with that of cells grown in suspension

L-M cells from a 2-day suspension culture were distributed, in fresh $199 \mathrm{P}$ mc, among six plastic flasks and one Erlenmeyer flask; the cells in the plastic flasks were grown as monolayers, and those in the Erlenmeyer as a suspension culture. At approximately $24 \mathrm{hr}$ intervals, the cells from two monolayers were harvested, and total and viable cell counts made. Counts were also made of samples of the suspension culture taken at the same time intervals.

It was found (Table I) that the viability of the cells scraped from the plastic after $24 \mathrm{hr}$ was only 12 per cent, by comparison with the 99 per cent viability of the suspension culture. On succeeding days, the viability of the cells obtained from the monolayers increased. The unstained (viable) cells were spherical, whereas many of those which took up the dye retained the form they had had while attached to the plastic; in some of these stained cells the nuclei could be distinguished.

Relationship of uptake of dye to mechanical removal from plastic, and to loss of viability

L-M cells from a 2 day suspension culture were suspended in fresh $199 \mathrm{P}$ mc seeded into eight plastic bottles and incubated at $37^{\circ} \mathrm{C}$. After $23 \mathrm{hr}$, the medium in each flask was replaced with fresh $199 \mathrm{P}$ mc. To four flasks erythrosin

TABLE I.

\begin{tabular}{|c|c|c|c|c|c|c|}
\hline \multirow[b]{2}{*}{ Hours in culture } & \multicolumn{2}{|c|}{24} & \multicolumn{2}{|l|}{46} & \multicolumn{2}{|c|}{72} \\
\hline & Monolayer & Susp. ${ }^{a}$ & Monolayer & Susp. & Monolayer & Susp. \\
\hline Cell count $\left(10^{5} / \mathrm{ml}\right)$ & 2.42 & 2.67 & 4.02 & 4.83 & 6.06 & 5.97 \\
\hline Viability, \% & 12 & 99 & 63 & 96 & 86 & 97 \\
\hline
\end{tabular}

${ }^{a}$ Suspension.

In this, and in other tables, the values for cell count and viability are those obtained when the cells were harvested at the conclusion of an experiment or stage of an experiment. 
13 was added to give a concentration of 0.1 per cent; approximately $4 \mathrm{ml}$ of medium were removed from each flask, and the cultures were examined with an inverted microscope for the presence of stained cells. The cells in the remaining four flasks were scraped off the plastic, and total and viable counts made of samples from every flask; the suspensions were then reseeded into fresh plastic bottles and returned to the incubator. They were inspected with the inverted microscope after $6 \mathrm{hr}$, and harvested for estimation of total and viable cell counts after $24 \mathrm{hr}$.

It was found that, of the cells exposed to erythrosin B but not removed from the plastic, 90 per cent remained unstained. By contrast, when cells were scraped from the flask wall the proportion of cells unstained fell to 20 per cent. The harvested suspensions, $6 \mathrm{hr}$ after reseeding, showed very few cells attached to the plastic and much debris in the supernatant medium. After $24 \mathrm{hr}$ (Table II) the number of cells attached to the plastic was $0.65 \times$ $10^{5} / \mathrm{ml}-21.5$ per cent of the original inoculum. Of the cells still floating in the medium, 23 per cent (12.8 per cent of the original inoculum) were unstained and spherical, and therefore presumably still viable. The proportion of stained cells that could be shown, by further cultivation, to be dead was therefore at least 82.1 per cent.

These results indicated that the mechanical removal of the cells from the plastic was associated with an increased permeability to erythrosin 13 , due probably to some damage to the cell membrane which varied in degree and was often lethal.

Effect of cell density on viability of cells scraped from plastic

The purpose of this experiment was to test whether the low viability of cells scraped from plastic after $24 \mathrm{hr}$ incubation was due to the fact that, in

TABLE II. Correlation of uptake of dye with removal from plastic and loss of viability.

\begin{tabular}{lccc}
\hline & $\begin{array}{c}\text { Grown on plastic for 24 hr. } \\
\text { on plastic } \\
\text { for } 24 \mathrm{hr} . \\
\text { Removed } \\
\text { by scraping }\end{array}$ & $\begin{array}{c}\text { Scraped off plastic. Reseeded } \\
\text { into fresh plastic bottles; } \\
\text { incubated a further } 24 \mathrm{hr}\end{array}$ \\
$\begin{array}{c}\text { Cells still in } \\
\text { suspension }\end{array}$ & $\begin{array}{c}\text { Removed } \\
\text { by scraping }\end{array}$ \\
\hline $\begin{array}{l}\text { Treatment of culture } \\
\% \text { cells unstained }\end{array}$ & 3.02 & 1.68 & 0.65 \\
\hline
\end{tabular}


the sparse cultures produced after this period, the cells were better spread than in older cultures, and thus a greater surface of cell membrane was liable to be damaged during mechanical removal.

Suspensions containing graded concentrations of cells in fresh $199 \mathrm{P}$ me were prepared from a 2 day suspension culture of L-M cells. Graded volumes of the most concentrated suspension were introduced into one series of plastic bottles, and the other suspensions were distributed among a second series, each bottle of which received $5 \mathrm{ml}$ of suspension. After $24 \mathrm{hr}$ incubation, the cells were harvested into the same volume of fresh medium as that in which they had been grown, and the usual estimations made.

As shown in Table III, the concentration of cells $/ \mathrm{ml}$ culture medium had a greater effect on viability after mechanical removal than did the number of cells per unit area of growth surface, within the range tested. For example, if the final cell count was $4.25 \times 10^{5}$ cells $/ \mathrm{ml}$, and there were $10.6 \times 10^{5}$ cells/ flask, the viability was 52 per cent; whereas with a concentration of $2.63 \times$ $10^{5}$ cells $/ \mathrm{ml}$, and $13 \cdot 15 \times 10^{6}$ cells/flask, the viability was 26 per cent. These results indicated that the lower viability of cells scraped from plastic after $24 \mathrm{hr}$ incubation was not due entirely to the greater spreading of cells in sparse cultures. They suggested that some substance produced by the cells might play a part in increasing the viability of cells removed mechanically after long periods of cultivation, and that with a sufficiently dense inoculum the concentration of this substance would have reached a protective level within $24 \mathrm{hr}$.

Effect of different media on the viability of cells scraped from plastic

The test cells for this experiment were derived from suspension cultures, and monolayers on glass, both of which were 2 days old. Aliquots of the cells

TABLE III. Effect of cell density on viability of cells scraped from plastic.

\begin{tabular}{cccc}
\hline $\begin{array}{c}\text { Volume of } \\
\text { medium }(\mathrm{ml})\end{array}$ & Cells/ml & Cells/flask & Viability, \% \\
\hline 5 & $5.67 \times 10^{5}$ & $28.4 \times 10^{5}$ & 69 \\
5 & $5.11 \times 10^{5}$ & $25.6 \times 10^{5}$ & 58 \\
2.5 & $4.25 \times 10^{5}$ & $10.6 \times 10^{5}$ & 52 \\
2.5 & $3.96 \times 10^{5}$ & $9.9 \times 10^{5}$ & 49 \\
1.25 & $3.23 \times 10^{5}$ & $4.0 \times 10^{5}$ & 37 \\
1.25 & $2.35 \times 10^{5}$ & $2.9 \times 10^{5}$ & 35 \\
5 & $2.63 \times 10^{5}$ & $13.15 \times 10^{5}$ & 26 \\
5 & $1.33 \times 10^{5}$ & $6.6 \times 10^{5}$ & 10 \\
5 & $1.42 \times 10^{5}$ & $7.1 \times 10^{5}$ & 7 \\
\hline
\end{tabular}

Experimental Cell Research $\mathbf{4 6}$ 
from the suspension culture were suspended in fresh $199 \mathrm{P} \mathrm{mc}$, or in medium in which cells had been grown in suspension for $48 \mathrm{hr}$ ('suspension-conditioned" $199 \mathrm{P} \mathrm{mc}$ ), or in the supernatant medium from $48 \mathrm{hr}$ monolayer cultures ("monolayer-conditioned" $199 \mathrm{P}$ mc). The medium of the monolayer cultures was replaced with fresh $199 \mathrm{P}$ mc, and the cells were scraped from the glass and suspended in this. After estimation of total and viable cell counts, one aliquot of the suspension was diluted with fresh $199 \mathrm{P}$ me to give a cell concentration of approximately $2 \times 10^{5} / \mathrm{ml}$. Two other aliquots were centrifuged and the cells were resuspended in either suspension-conditioned or monolayer-conditioned $199 \mathrm{P}$ mc.

Four plastic flasks were seeded with each of the six suspensions thus obtained, and after $24 \mathrm{hr}$ incubation the cells were harvested, and total and viable cell counts made in the usual way.

The design of the experiment, and the results obtained, are shown in Text-Fig. 1. Cells plated out from monolayer cultures showed a high viability

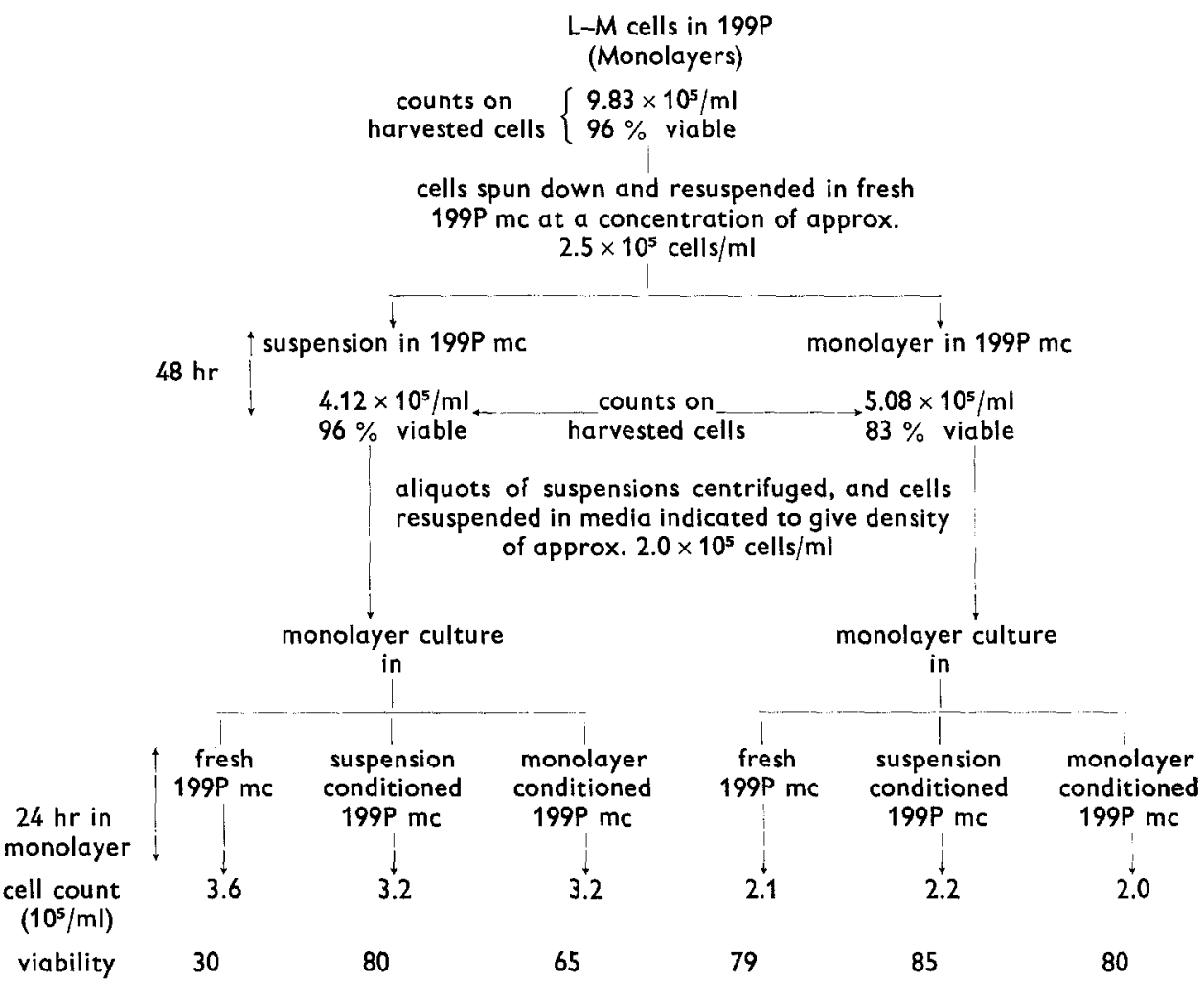

Text-Fig. 1.-Effect of different media on viability of cells scraped from plastic. 
after scraping even when grown in fresh $199 \mathrm{P}$ mc; for cells seeded from suspension, "conditioned" medium gave a much higher viability than fresh, the suspension-conditioned medium being more effective than the monolayerconditioned.

These results indicated that a protective substance was produced during cultivation of L-M cells either in suspension or monolayer. The high viability of the cells explanted from monolayer in fresh $199 \mathrm{P}$ mc in which they had been scraped from glass further indicated that this substance became enmeshed between the cells and the substrate in monolayer culture and was released when the cells were scraped free. The reduced protection afforded to cells explanted from suspension by the supernatant from the monolayer cultures might also be due to the entrapment of the protective substance between the cells of a monolayer, with only partial release into the supernatant medium during cultivation.

Effect of different media on the viability of cells plated from monolayer onto plastic

Two-day-old monolayer cultures of L-M cells were used to provide the cells. The medium from one group of bottles was removed and kept, and replaced with fresh $199 \mathrm{P}$ mc. The cells were then scraped off in this fresh medium and, after estimations of total and viable cell counts had been made, 5 aliquots of the suspension were centrifuged. The cells from another group of the cultures were scraped from the glass in the medium in which they had been grown. The resulting suspension, after removal of a sample for total and viable cell counts, was centrifuged; the cells were discarded and the supernatant medium kept. An appropriate volume of medium from a 2-dayold suspension culture of L-M cells was also obtained by centrifugation.

One of the 5 aliquots of cells obtained from the first group of monolayer cultures was then explanted in plastic flasks in each of the following media: fresh $199 \mathrm{P}$ mc; the supernatant medium from 2-day monolayer cultures; fresh medium in which cells had been scraped from glass; medium in which monolayers had been grown and subsequently scraped from glass; and medium in which cells had been grown in suspension for 2 days. The procedure by which these media were obtained is summarized in Text-Fig. 2.

After 2 days' incubation of the test monolayers, the cells were harvested and the usual estimations made. As shown in Table IV, the cells grown in fresh medium had a viability, after mechanical removal, of 51 per cent; this was higher than that of cells seeded from suspension and similarly treated (Tables I-III, Text-Fig. 1). The viability was further increased if the cells 
Monolayers (Set 1)

Medium removed and used for suspension of aliquot (2) of monolayers of Set 1.

Cells scraped from glass in fresh 199P mc*; aliquots of suspension centrifuged, and suspended in:

(1) fresh 199P mc;

(2) medium removed from cultures of Set 1 before these were scraped from glass;

(3)* fresh 199P mc in which cultures of Set 1 scraped from glass;

(4) medium in which monolayers of Set 2 scraped from glass;

(5) medium from suspension culture of L-M cells.

Monolayers (Set 2)

Cells scraped from glass in medium in which they were grown.

Suspension centrifuged.

Cells discarded.

Medium used for suspension of aliquot (4) of monolayers of Set 1.

Text-Fig. 2.--Procedure used in setting up expt. (5).

were grown in conditioned medium or in medium in which 2-day cultures had been scraped from glass.

These results suggested that a "protective substance", probably of high molecular weight, was attached to both cells and substrate in monolayer cultures, but remained free in the medium in suspension cultures.

The effect of dialysis on the protective action of suspension-conditioned medium

The medium used was from a $48 \mathrm{hr}$ culture. Dialysis was against either an equal volume of fresh $199 \mathrm{P}$ me for $48 \mathrm{hr}$ (1:1 dialysis) or against two successive lots, each of ten times the volume, of fresh 199P me for $24 \mathrm{hr}$ each (1:100 dialysis).

From a 2-day suspension culture test monolayers on plastic were set up in one of the following media: fresh 199P me, suspension-conditioned $199 \mathrm{P}$ mc either undiluted or diluted with an equal volume of fresh 199P me, or the

'TABLE IV. Effect of different media on viability of cells plated from monolayer onto plastic, and removed by scraping after $24 \mathrm{hr}$.

\begin{tabular}{lcc}
\hline \multicolumn{1}{c}{ Medium } & $\begin{array}{c}\text { Cell count } \\
\left(10^{5} / \mathrm{ml}\right)\end{array}$ & $\begin{array}{c}\text { Viabil- } \\
\text { ity, \% }\end{array}$ \\
\hline Fresh 199P mc & 2.65 & 51 \\
Monolayer-conditioned 199P me & 2.22 & 76 \\
Fresh 199P me in which cells scraped & & \\
$\quad$ from glass & 2.40 & 79 \\
Monolayer-conditioned 199P mc in & & 82 \\
$\quad$ which cells scraped from glass & 2.48 & 88 \\
Suspension-conditioned 199P mc & 1.90 & \\
\hline
\end{tabular}


dialysates or residues from the two dialyses. The cultures were harvested after $24 \mathrm{hr}$, and the usual estimations made.

The results of two such experiments are shown in Table $\mathrm{V}$. The protective action was present only in the non-dialysable fraction of the conditioned medium; this again indicated that the substance involved was of high molecular weight.

Effect of filtration through sterilizing filters on the protective action of suspension-conditioned medium

Samples of medium from a $48 \mathrm{hr}$ suspension culture were filtered through a cellulose acetate membrane filter of pore size $0.45 \mu$, or through a sintered glass filter of UF grade. Aliquots of cells from a $48 \mathrm{hr}$ suspension culture were suspended in the filtered samples; controls were provided by cells

TABle V. Effect of dialysis on protective action of suspension-conditioned medium.

\begin{tabular}{lccccc}
\hline \multicolumn{1}{c}{ Medium } & \multicolumn{2}{c}{ Experiment 1} & & \multicolumn{2}{c}{ Experiment 2} \\
\hline Fresh 199P me & $\begin{array}{c}\text { Cell count } \\
\left(10^{5} / \mathrm{ml}\right)\end{array}$ & $\begin{array}{c}\text { Viability } \\
\%\end{array}$ & $\begin{array}{c}\text { Cell count } \\
\left(10^{5} / \mathrm{ml}\right)\end{array}$ & $\begin{array}{c}\text { Viability } \\
\%\end{array}$ \\
Suspension-conditioned 199P me & 3.52 & 20 & 3.39 & 30 \\
Equal parts fresh and suspension- & 3.23 & 81 & 2.99 & 79 \\
$\quad$ conditioned 199P me & & & & \\
$1: 1$ dialysis residue & 3.93 & 78 & 3.30 & 70 \\
$1: 1$ dialysis dialysate & 3.22 & 75 & 3.01 & 76 \\
$1: 100$ dialysis residue & 3.16 & 13 & 2.48 & 12 \\
$1: 100$ dialysis dialysate & 3.73 & 82 & 3.26 & 79 \\
\hline
\end{tabular}

TABLE VI. Effect of filtration on protective action of suspension-conditioned medium.

\begin{tabular}{lcccc}
\hline Medlum & Fresh 199P mc & Unfiltered & $\begin{array}{c}\text { Conditioned 199P me } \\
\text { through } 0.45 \mu \\
\text { pore membrane }\end{array}$ & $\begin{array}{c}\text { Filtered } \\
\text { through UF- } \\
\text { sintered glass }\end{array}$ \\
\hline $\begin{array}{l}\text { Cell count }\left(10^{5} / \mathrm{ml}\right) \\
\text { Viability, } \%\end{array}$ & 2.15 & 2.43 & 1.94 & 2.48 \\
\hline
\end{tabular}


suspended in unfiltered fresh and suspension-conditioned 199P me. Monolayer cultures were set up on plastic, and harvested after $24 \mathrm{hr}$.

The results (Table VI) showed that the substance would pass through a "Millipore" filter of pore size $0.45 \mu$, but was removed by a sintered glass filter. This suggested that, although present in solution in the medium, it was adsorbed onto the glass filter. It seemed possible that the substance might be similarly adsorbed onto the plastic culture flasks and thus provide an alternative substrate for cells seeded into them.

Adsorption of protective substance by plastic

Plastic flasks were exposed for $3 \mathrm{hr}$ at $37^{\circ} \mathrm{C}$ to either fresh or suspensionconditioned 199P mc; the surfaces were then washed with fresh medium. Cells from a $48 \mathrm{hr}$ suspension culture were suspended in fresh $199 \mathrm{P}$ me and explanted into the flasks; the cultures were harvested after $24 \mathrm{hr}$.

The results (Table VII) showed that pretreatment of the plastic flasks with conditioned medium reduced the damage sustained by monolayer cultures grown in them and subsequently removed by scraping, whereas a similar pretreatment with fresh $199 \mathrm{P}$ me did not. These findings again suggested that the adsorption of some substance from conditioned medium onto the plastic might be concerned in the protective action of the medium.

The viability of cells removed from glass

Twelve new French square bottles were divided into groups of three. One group was rinsed with tap water and distilled water; one was washed in the detergent usually used for the tissue culture glassware in this laboratory, and then in tap water and distilled water; one was rinsed with acelone, alcohol and distilled water; and one was subjected to successive half-hour exposures to $N \mathrm{NaOH}$ and $N \mathrm{HCl}$, followed by rinses in tap and distilled water. All the bottles were then dried and sterilized in the autoclave.

Cells from a 2-day suspension of L-M cells were suspended in fresh $199 \mathrm{P}$ mc

TABLE VII. Adsorption of protective substance by plastic.

\begin{tabular}{lcccccc}
\hline $\begin{array}{l}\text { Treatment } \\
\text { of plastic }\end{array}$ & \multicolumn{2}{c}{ Conditioned 199P me } & & \multicolumn{2}{c}{ Fresh 199P mc } \\
\cline { 2 - 4 } & No wash & One wash & Two washes & & No wash & One wash \\
Cell count $\left(10^{5} / \mathrm{ml}\right)$ & 3.51 & 3.75 & 3.60 & 3.59 & 3.47 \\
Viability, \% & 86 & 75 & 77 & 30 & 34 \\
\hline
\end{tabular}


for inoculation of the culture bottles; the monolayers were harvested for counting after $24 \mathrm{hr}$ incubation.

It was found (Table VIII) that the number of cells attached to the glass after $24 \mathrm{hr}$ incubation varied widely among the bottles. The viability of the

TABLE VIII. Viability of cells scraped from French square bottles.

\begin{tabular}{|c|c|c|c|c|}
\hline Treatment of glass & Water & Detergent $-\mathrm{H}_{2} \mathrm{O}$ & $\begin{array}{c}\text { Acetone- } \\
\text { alcohol- } \mathrm{H}_{2} \mathrm{O}\end{array}$ & $\begin{array}{c}\mathrm{NaOH}- \\
\mathrm{HCl}-\mathrm{H}_{2} \mathrm{O}\end{array}$ \\
\hline Cell count $\left(10^{5} / \mathrm{ml}\right)$ & $1.84 ; 2.90 ; 3.20$ & $3.23 ; 1.89 ; 3.54$ & $1.99 ; 3.72 ; 2.35$ & $1.23 ; 1.32 ; 0.73$ \\
\hline Viability, \% & $92 \quad 90$ & 84 & 89 & 94 \\
\hline
\end{tabular}

cells after mechanical removal was, however, high, and apparently unaffected by the method by which the bottles had been washed.

Test for production of protective substance by 24 hr cultures grown on glass or plastic

It seemed that the difference between the viabilities of cells scraped from glass and plastic might be due to one of three causes: a difference in the attachment of the cells to the two surfaces; a more rapid production of the protective substance by cells grown on glass; or the presence of some substance, leached from the plastic during incubation of the culture, which rendered the cell membrane more fragile.

To test the second of these possibilities, cells from a $48 \mathrm{hr}$ suspension culture of L-M cells were suspended in fresh $199 \mathrm{P}$ me and distributed among four glass and four plastic culture flasks. After $24 \mathrm{hr}$ incubation, the supernatant media from the glass bottles were pooled, as were those from the plastic flasks. The monolayers were harvested in fresh 199P mc, and samples taken for estimation of total and viable cell counts. The remaining suspensions were divided into two pools, from glass and plastic bottles respectively, and centrifuged. The supernatant media from these centrifugations, and the monolayer culture media, were then used as suspending media for cells from a $48 \mathrm{hr}$ suspension culture of $\mathrm{L}-\mathrm{M}$ cells; these were inoculated into plastic bottles, and after $2 \mathrm{hr}$ incubation the cells were harvested by scraping and the usual estimations made.

As shown in Table IX, the only medium that gave any protection to the test cells was that in which the 24 -hr culture on plastic had been removed. It seems probable that this was due to the release of the protective substance 
from damaged cells into the medium. The results did not suggest that cells grown on glass synthesized the substance more rapidly than those grown on plastic.

Tests for presence of toxic substance in plastic

Two experiments were made. In the first, fresh or suspension conditioned $199 \mathrm{P}$ mc was incubated in plastic flasks at $37^{\circ} \mathrm{C}$ for $2 \mathrm{hr}$, and then used as the medium for cells seeded, from a 2 -day suspension culture, into French square glass bottles. The plastic flasks were washed twice with fresh medium, and a further $5 \mathrm{ml}$ lot of fresh $199 \mathrm{P} \mathrm{mc}$ was incubated in each for $2 \mathrm{hr}$; this medium was then used as the culture medium for a second sample of cells seeded from suspension onto glass. Controls were provided by cultures inoculated into glass bottles in fresh 199P mc. After $2 \mathrm{hr}$ incubation, the medium in the bottles was replaced with fresh $199 \mathrm{P}$ me, and the cells were scraped off the glass for estimation of total and viable cell counts.

The results, shown in Table $\mathrm{X}$, indicated that a substance which slightly increased the fragility of the cells was removed from the bottles within $2 \mathrm{hr}$

TABLE IX. Test for production of protective substance by 24 hr cultures.

\begin{tabular}{|c|c|c|c|c|c|}
\hline \multirow[b]{2}{*}{ Medium } & \multirow[b]{2}{*}{$\begin{array}{c}\text { Fresh } \\
\text { 199P mc }\end{array}$} & \multicolumn{2}{|c|}{$\begin{array}{c}\text { Supernatant from } \\
\text { cultures on }\end{array}$} & \multicolumn{2}{|c|}{$\begin{array}{l}\text { Medium in which } \\
\text { cells removed }\end{array}$} \\
\hline & & $\begin{array}{c}\text { Glass } \\
\text { (French } \\
\text { square) }\end{array}$ & Plastic & $\begin{array}{c}\text { Glass } \\
\text { (French } \\
\text { square) }\end{array}$ & Plastic \\
\hline Cell count $\left(10^{5} / \mathrm{ml}\right)$ & $1.42 ; 1.14$ & $1.44 ; 1.43$ & $1.47 ; 1.48$ & $1.54 ; 1.49$ & $1.61 ; 1.61$ \\
\hline Viability，\% & 2 & 4 & 9 & $6 ; \quad 12$ & $87 \quad 87$ \\
\hline
\end{tabular}

TaBle X. Test for leaching of toxic substance from plastic.

\begin{tabular}{lccccc}
\hline & \multicolumn{4}{c}{$\begin{array}{c}\text { Fresh 199P mc } \\
\text { Pre-incubated with } \\
\text { plastic washed with }\end{array}$} \\
\multicolumn{1}{c}{ Medium } & Untreated & $\begin{array}{c}\text { Pre-incubated } \\
\text { with plastic }\end{array}$ & $\begin{array}{c}\text { Fresh } \\
199 \mathrm{P} \text { mc }\end{array}$ & $\begin{array}{c}\text { Conditioned } \\
\text { 199P me }\end{array}$ & $\begin{array}{c}\text { Conditioned } \\
\text { 199P mc }\end{array}$ \\
\hline $\begin{array}{l}\text { Cell count }\left(10^{5} / \mathrm{ml}\right) \\
\text { Viability, \% }\end{array}$ & $\mathbf{1 . 7 6}$ & $\mathbf{1 . 9 4}$ & 1.57 & 1.88 & 2.04 \\
\hline
\end{tabular}

Washed plastic: plastic that had been incubated with fresh or conditioned $199 \mathrm{P}$ me for $2 \mathrm{hr}$ and then washed twice with fresh $199 \mathrm{P}$ me. 
at $37^{\circ} \mathrm{C}$ by fresh, and possibly by conditioned medium. A further $2 \mathrm{hr}$ treatment of the surface with either medium apparently released no more of the substance.

In the second experiment, "Falcon" plastic tissue culture dishes were treated for $16 \mathrm{hr}$ with either concentrated sulphuric acid or alcoholic caustic potash and subsequently, after thorough washing with distilled water and medium, used as culture vessels for L-M cells seeded from suspension in fresh $199 \mathrm{P}$ mc. For controls, cells were seeded into untreated similar dishes. After $2 \mathrm{hr}$ incubation, the cells in one dish of each set of cultures were treated with erythrosin B in situ. Those from the other dishes were scraped off, and total and viable cell counts were made.

In the three groups of dishes, the viability of the cells while still attached to the plastic was over 95 per cent. No difference was found among the three in the low viability of the cells removed by scraping ('Table XI).

\section{The attachment of cells to different substrates}

It was noticed that cells grown in French square bottles were less well spread than those grown on plastic; the difference was more noticeable after $2 \mathrm{hr}$ incubation than after $24 \mathrm{hr}$. It was possible, therefore, that the difference between the viabilities of cells removed from the two substrates was due to a quantitative rather than a qualitative difference in attachment; that is, that smaller areas of the membranes of cells grown in these glass vessels were firmly attached, and that there was therefore less extensive damage to the membrane when the cells were removed.

In an experiment designed to test the relationship between degree of spreading, firmness of attachment, and viability following mechanical removal, cells from a 2-day suspension culture of L-M cells were suspended in fresh 199P me and inoculated into French square and plastic bottles that had been previously exposed for $2 \mathrm{hr}$ at $37^{\circ} \mathrm{C}$ to either fresh or suspension-conditioned medium. After $2 \mathrm{hr}$ incubation, the cultures were examined with an inverted microscope

TABLE: XI. Viability of cells scraped from plastic pretreated by methods designed to remove a possible toxic factor.

\begin{tabular}{cllc}
\hline \multicolumn{1}{c}{ Pretreatment } & None & Conc. $\mathrm{H}_{\mathbf{2}} \mathrm{SO}_{4}$ & $\begin{array}{c}\text { Alcoholic } \\
\mathbf{K O H}\end{array}$ \\
\hline Cell count $\left(10^{5} / \mathrm{ml}\right)$ & 1.99 & 1.91 & 1.92 \\
Viability, $\%$ & 4 & 3 & 2 \\
\hline
\end{tabular}


and the degree of spreading of the cells was estimated. The monolayers in half the bottles were flushed ten times with a jet of medium from a Pasteur pipette, and the number of cells released from each was counted. The medium in these bottles was then replaced with fresh $199 \mathrm{P}$ mc; the remaining cells were scraped off and total and viable cell counts made. The other cultures were similarly treated after they had been incubated for $24 \mathrm{hr}$.

The appearance of the cells on the different substrates, $2 \mathrm{hr}$ after seeding, is shown in Fig. 1. Cells grown on either glass or plastic that had been pretreated with conditioned medium were well spread; those explanted on plastic pretreated with fresh medium showed some spreading, while those in the French square bottles pretreated with fresh medium were still almost all spherical.

After $2 \mathrm{hr}$ incubation almost half of the cells seeded in French square bottles pretreated with fresh medium could be removed by vigorous pipetting. Of the cells on the other surfaces, however, approximately 90 per cent were firmly attached within $2 \mathrm{hr}$ (Table XII). The viability of cells scraped from all the substrates, except plastic pretreated with fresh medium, was high (Table XII).

In cultures incubated for $24 \mathrm{hr}$ on the same substrates the proportions of cells firmly attached were 90 per cent (for French square bottles pretreated with fresh medium) and 96 per cent (for the other surfaces). The viability of cells removed from the glass pretreated with either medium was 91 per cent, by comparison with 77 per cent for plastic pretreated with conditioned medium and 19 per cent for plastic pretreated with fresh medium.

TABLE XII. Attachment of cells to different substrates.

\begin{tabular}{|c|c|c|c|c|c|}
\hline \multirow[b]{2}{*}{ Surface } & \multicolumn{2}{|c|}{$\begin{array}{l}\text { French square } \\
\text { glass bottles } \\
\text { pretreated with }\end{array}$} & \multicolumn{2}{|c|}{$\begin{array}{l}\text { Plastic } \\
\text { pretreated with }\end{array}$} & \multirow{2}{*}{$\begin{array}{l}\text { Glass prescrip- } \\
\text { tion bottles } \\
\text { Untreated }\end{array}$} \\
\hline & $\begin{array}{c}\text { Fresh } \\
\text { 199P me }\end{array}$ & $\begin{array}{l}\text { Conditioned } \\
199 \mathrm{P} \text { me }\end{array}$ & $\begin{array}{l}\text { Fresh } \\
199 \mathrm{P} \text { me }\end{array}$ & $\begin{array}{l}\text { Conditioned } \\
199 \mathrm{P} \text { me }\end{array}$ & \\
\hline \multicolumn{6}{|l|}{$2 h r$ incubation } \\
\hline Cell count $\left(10^{5} / \mathrm{ml}\right)$ & 1.14 & 2.20 & 2.18 & 2.19 & 2.08 \\
\hline$\%$ firmly attached & 55.1 & 88.8 & 91.0 & 92.0 & 92.0 \\
\hline Viability, \% & 90 & 91 & 6 & 83 & 24 \\
\hline \multicolumn{6}{|l|}{$24 \mathrm{hr}$ incubation } \\
\hline Cell count $\left(10^{5} / \mathrm{ml}\right)$ & 3.29 & 3.49 & 3.50 & 3.55 & 2.26 \\
\hline$\%$ firmly attached & 90 & 95.7 & 96.1 & 95.7 & 95.0 \\
\hline Viability, \% & 91 & 91 & 19 & 77 & 72 \\
\hline
\end{tabular}



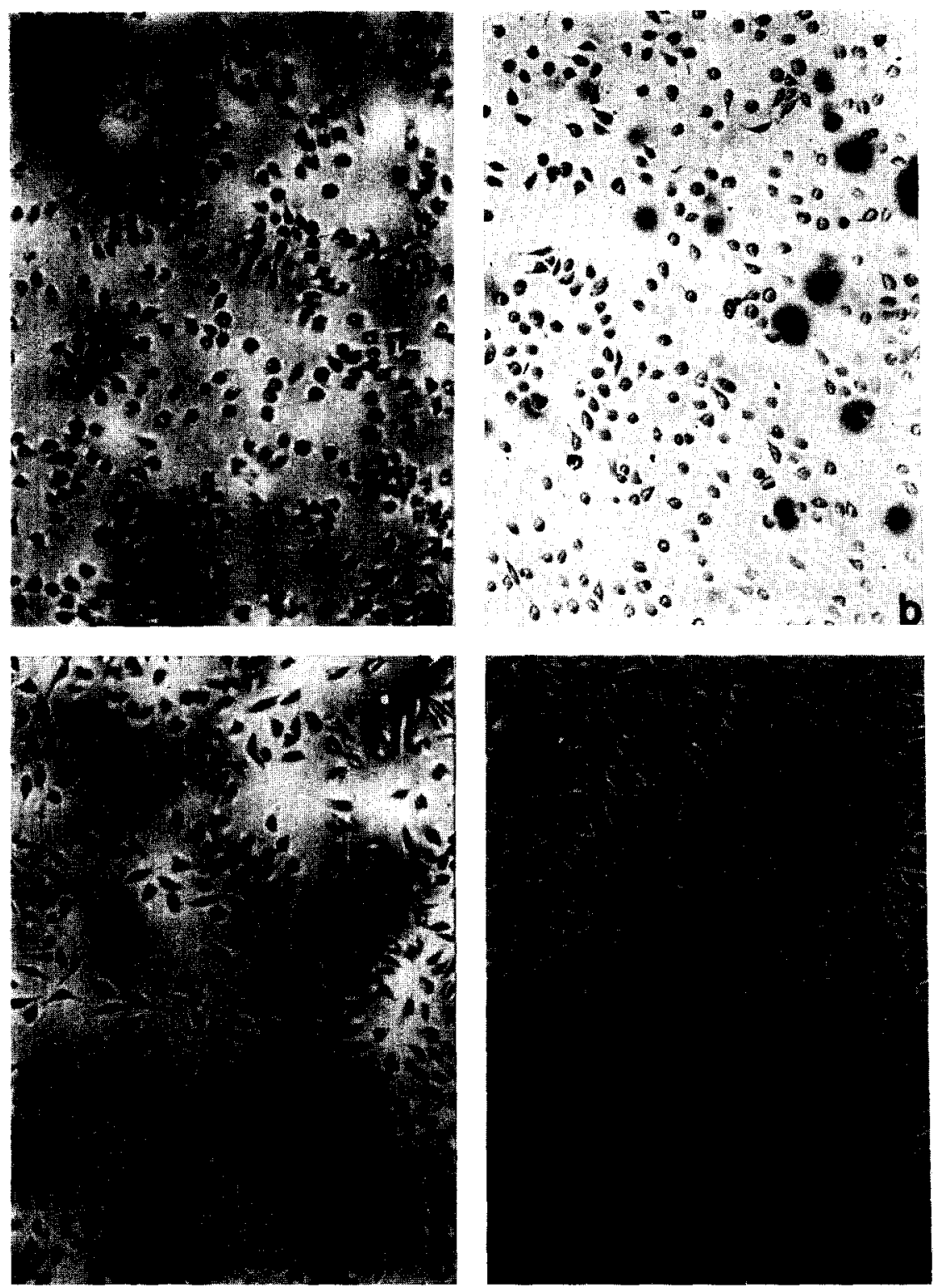

Fig. 1.-Living cultures of $\mathbf{L}-\mathbf{M}$ cells, 2 hr after explantation. $\times$ 77. $a$, Plated in French square bottles pretreated with fresh $199 \mathrm{P}$ mc. Some cells are spreading out but most are still spherical; $b$, Plated on plastic pretreated with fresh 199P mc. Most cells show some processes, and some are well spread; $c$, Plated in French square bottles pretreated with conditioned 199P mc. Most cells are well spread; $d$, Plated on plastic pretreated with conditioned $199 \mathrm{P}$ mc. Almost all the cells are very well spread. 
In a later experiment, $20 \mathrm{z}$ glass prescription bottles (Universal glass bottles) were used as the culture vessels. These were washed by the Calgon-metasilicate method described by Paul [7]. Cells from a 2-day suspension culture were seeded into them in fresh medium and, after $2 \mathrm{hr}$ incubation, the cultures were inspected. The number of cells released by vigorous pipetting was then estimated, and total and viable counts made of the firmly attached cells.

In these glass bottles, the cells were well spread after $2 \mathrm{hr}$. A high proportion of the cells was firmly attached to the surface, and many of these were killed on mechanical removal (Table XII). The proportion of cells that survived this treatment was increased after $24 \mathrm{hr}$ incubation.

Protective action of conditioned media for $L-M 2 \times E$ cells

Two suspension cultures were used to provide the cells. Both were $48 \mathrm{hr}$ old, but in one the medium was $199 \mathrm{P} \mathrm{mc}$ and in the other $2 \times \mathrm{E}$ containing 0.24 per cent methocel $(2 \times \mathrm{E} / 2 \times \mathrm{mc})$. Two aliquots of each suspension were centrifuged, and the cells suspended in either the medium in which they had been grown or the corresponding fresh medium. These suspensions were inoculated into plastic flasks and the cultures incubated for $24 \mathrm{hr}$. The medium in each flask was then replaced with the appropriate fresh medium and the cells were harvested for the usual estimations.

As shown in Table XIII, the viability of the L-M $2 \times \mathrm{E}$ cells after mechanical removal was increased if they had been grown in either conditioned medium.

Preliminary attempts to identify the protective substance have indicated that macromolecular products of the cells with differing chemical properties are equally effective in protecting the cells. Pretreatment of plastic surfaces with a 0.5 per cent solution of bovine serum albumin in $199 \mathrm{P}$ me also reduced the damage sustained by cells plated on these surfaces and subsequently removed by scraping. Cells seeded onto albumin-treated surfaces were less

TABLE XIII. Protective action of suspension-conditioned media for $L-M 2 \times E$ cells.

\begin{tabular}{ccccc}
\hline Medium & $\begin{array}{c}\text { Fresh } \\
199 \mathrm{P} \text { mc }\end{array}$ & $\begin{array}{c}\text { Conditioned } \\
199 \mathrm{P} \text { mc }\end{array}$ & $\begin{array}{c}\text { Fresh } 2 \times \mathrm{E} / \\
2 \times \mathrm{mc}\end{array}$ & $\begin{array}{c}\text { Condi- } \\
\text { tioned } \\
2 \times \mathrm{E} / \\
2 \times \mathrm{mc}\end{array}$ \\
\hline Cell count $\left(10^{5} / \mathrm{ml}\right)$ & 1.66 & 1.85 & 2.17 & 2.24 \\
Viability, \% & 24 & 72 & 14 & 63 \\
\hline
\end{tabular}

Experimental Cell Research $\mathbf{4 6}$ 
well spread than those seeded on plastic pretreated with conditioned medium. It was also found that trypsin and ribonuclease, by adsorption onto plastic surface, altered the behaviour of cells subsequently plated on the plastic.

\section{DISCUSSION}

The results presented here show that treatment of glass or plastic surfaces with medium in which L-M cells have been grown ("conditioned" medium) causes an apparent alteration in the properties of these materials as substrates for cells seeded onto them. It is unlikely that samples of fresh and conditioned medium, of the same $\mathrm{pH}$, would have different effects on the intrinsic properties of glass or plastic; the most likely explanation of the results seems to be that $\mathrm{L}-\mathrm{M}$ cells grown either in suspension or monolayer synthesize a substance or substances of high molecular weight, which may be adsorbed onto glass or plastic and serve as a substrate for cells plated onto these surfaces.

If $\mathrm{L}-\mathrm{M}$ cells obtained from a suspension culture are resuspended in fresh medium, grown as monolayer cultures in plastic flasks for $24 \mathrm{hr}$, and removed by scraping, many are apparently severely damaged. The dye-exclusion method used here to estimate viability has been shown by Myers [6] to indicate relatively severe cell damage, compared with that shown by estimation of potassium leakage. The results of the present experiments indicated that over 80 per cent of the cells which were stained in the test would be found to be dead on further incubation.

L-M cells appear to be less firmly attached to some samples of glass than to others, to plastic or to a layer of their secreted macromolecular products adsorbed to either glass or plastic; the fundamental cause of the difference in attachment cannot be deduced from these experiments. Cells attached firmly to plastic or glass suffer more damage on mechanical removal than do those adhering to adsorbed secretion products. The higher viability of cells removed from some types of glass could be explained on the basis of the poorer spreading on, and weaker attachment to the substrate, with consequent limitation of the area of traumatization on mechanical detachment. Cells grown on adsorbed secretion products were, however, better spread than those grown on plastic or glass, and were no more readily removed by vigorous pipetting. It is possible that the mode of attachment to the artificial and biological substrates was the same, but that smaller areas of membrane were involved when the substrate was adsorbed secretion products; if this was so, then since the cells were well spread on the biological material, the areas of attachment were widely distributed over the cell surface. Alternatively, as 
suggested by Berwick and Coman [1], the mode of attachment might depend on the substrate. The other possible reason for the difference in the viabilities of cells removed from plastic and biological substrate is that, when cells were scraped from plastic pretreated with conditioned medium, the separation occurred at the protective substance-plastic interface, rather than through the cell membrane. The results of experiment $\tilde{j}$, in which cells from a 2-dayold monolayer culture on glass were used as the test material, indicated that some of the secreted substance was removed with the cells and remained attached to them after one wash with $199 \mathrm{P} \mathrm{mc}$; this may, however, occur only when relatively large amounts of the substance have been secreted.

An additional factor contributing to the damage of cells scraped from plastic bottles might be a toxic substance which was apparently removed from these by fresh, and possibly also by conditioned, medium and rendered cells more fragile. This could partly account for the lower viabilities of cells removed from plastic bottles, compared with those of cells scraped from glass of a type to which they were firmly attached. It is unlikely, however, that any of this material would remain in the plastic culture dishes exposed for $16 \mathrm{hr}$ to concentrated sulphuric acid or alcoholic caustic potash. The low viability of cells scraped from these, by comparison with that of cells removed mechanically from glass to which they were firmly attached, is therefore presumably not due to a toxic compound; it may instead indicate a difference in the mode of attachment of the cells to these two substrates. Additional evidence for the non-toxicity of "Falcon" plastic dishes for cells is provided by the demonstration by Ham [3] that it is possible to clone cells in a proteinfree medium in these, but not in glass petri dishes.

The firmer attachment of cells to French square glass bottles after $24 \mathrm{hr}$ incubation might be due to the secretion of sufficient material to act as a substrate at the points of attachment of the cells to the surface. The amount released into the medium during this period was, however, insufficient to protect cells plated on plastic from damage when they were scraped from this substrate (experiment 10). Weiss [11] has shown that when cells are sheared from a glass surface they leave behind a material, possibly the microexudate demonstrated by Rosenberg $[10]$, to which cells will attach more firmly than they will to glass pretreated with the supernatant medium from a $24 \mathrm{hr}$ culture. It seems possible that this material is similar to the "protective substance" produced by cultures of L-M cells. The results obtained in the present study suggest that in monolayer cultures, the secreted macromolecular substances adhere to both the cells and the substrate, whereas in suspension culture they are not attached to the cells. 
The finding that the macromolecular secretion products of cells, and serum albumin, may be adsorbed onto artificial substrates and alter cell attachment suggests that, in studies on the attachment of cells to surfaces, it may be difficult to draw valid conclusions unless the experiments are of shorl duration and the medium used is protein-free.

The proteins produced by L-M cells have not yet been completely characterized. The work of Eidam and Merchant [2] indicates that they include ribonucleoprotein, but other substances of high molecular weight also appear to be secreted; any of these could have acted as the protective substance in the present series of experiments. It is interesting that Rubin [9] has shown that medium obtained from high concentrations of embryonic chick cells contains a macromolecular factor which enhances the growth of small numbers of these cells. It seems probable that, as suggested by Moscona [5], the nature of the materials secreted by cells is important in morphogenetic movement, metastasis and invasion. The use of adsorbed films of such substances might provide a tool for the investigation of cellular interaction.

\section{SUMMARY}

L-M cells obtained from a suspension culture, if suspended in fresh serumfree medium and plated onto either plastic or glass to which they become firmly attached, have a low viability when scraped from the substrate within a few hours of seeding. If L-M cells from a suspension culture are grown on plastic in "conditioned" medium (medium in which cells have been grown), the viability after mechanical removal is high. Pretreatment of plastic with conditioned medium also greatly reduces the damage sustained by cells seeded onto it in fresh medium, and subsequently removed by scraping. If the test cells for seeding onto plastic surfaces in fresh medium are obtained from monolayer rather than suspension cultures, fewer are killed on mechanical removal.

These results are consistent with the hypothesis that cells in suspension and monolayer culture synthesize a substance or substances of high molecular weight which may be adsorbed onto an artificial surface and serve as a substrate for the cells. They also suggest that in monolayer culture the secreted substances become adherent to the cells and the substrate, whereas in suspension culture they are not attached to the cells.

This work was done during the tenure of a Sir Henry Wellcome Travelling Fellowship. I should like to thank Dr D. J. Merchant for his generous provision of facilities at his laboratory, and for fruitful discussions of the experiments. I am also grateful to Dame Honor Fell, F.R.S., for her critical reading of the manuscript. 


\section{REFERENCES}

1. Berwick, L. and Coman, D. R., Cancer Res. 22, 982 (1962).

2. Elinam, C. R. and Merchant, D. J., Exptl Cell Res. 37, 132, 147 (1965).

3. Нам, F. G., Proc. Nall Acad. Sci. 53, 288 (1965).

4. Hsu, T. C. and Merchant, D. J., J. Natl Cancer Inst. 26, 1075 (1961).

5. Moscona, A. A., Intern. Rev. Exptl Pathol. 1, 371 (1962).

6. Myers, D. K., Exptl Cell Res. 38, 354 (1965).

7. Paul, J., Cell and Tissue Culture. G. S. Livingstone, 1959.

8. Phillips, H. J. and Terryberry, J. E., Exptl Cell Res. 13, 341 (1957).

9. Rumin, H., Exptl Cell Res. 41, 138 (1966).

10. Rosenberg, M. D., Biophys. J. 1, 137 (1960).

11. Weiss, L., Exptl Cell Res. 25, 504 (1961). 